\title{
Motivational Interviewing and Social Justice
}

\author{
WIliam R. Miller, PhD ${ }^{1}$
}

\begin{abstract}
This address explores the relationship between motivational interviewing (MI) and six broad humane values: compassion, respect, fairness, human potential, prizing of differences, and collaboration. These values are implicit in the spirit and practice of MI, and have implications far beyond professional practice.
\end{abstract}

Keywords

Compassion, Motivational Interviewing, Social Justice

$\mathrm{O}$ ne of the few published criticisms of motivational interviewing is that it "ignores the reality of the impact of the social surround" and that "an MI session is a small part of the client's life." In voicing this critique, Stanton (2010) was referring to important social determinants of motivation that lie outside the consulting room. Fair enough. We have focused on the dynamics of therapeutic interaction, and have never tried to propose a comprehensive theory of behavior change (Miller \& Rose, 2009, 2010). It is important to remember that volition is only one factor in change, albeit a vital one (Miller \& Atencio, 2008).

But I want to go Stanton one better. I decided with my plenary this year to go out on a limb, with a call for a consciousness of social justice that is implied by and reaches beyond the spirit of MI. Said another way, I believe that $\mathrm{MI}$ is a small part of something much larger, and it is to this larger reality that I want to speak today. Steve Rollnick asked me, "Miller, are you moving the tent pegs of MI again?" I think not. Rather I am reflecting on a much larger field in which we pitched the tent. What I will say here is based on no more than my personal reflections and sensibilities after 30 years of living with MI.

\section{THE DISSEMINATION OF MI: FASCINATIONS}

It is, I believe, no accident that motivational interviewing has usually found its home first among some of the most despised, rejected, and marginalized members of society: people with alcoholism, drug addiction, psychoses, HIV and AIDS; the homeless, sex workers, and criminal offenders-those for whom humane treatment is most unexpected, most welcome, and most impactful. Compassionate and respectful treatment of those who are most excluded has been a hallmark of $\mathrm{Ml}$ from its very beginning-even moreso, perhaps, than was the case for client-centered counseling, which developed within the more

\footnotetext{
${ }^{1}$ University of New Mexico

A version of this paper was presented as a plenary address at the MINT Forum, Fort Wayne, NM, September, 2012.
}

The author reports no conflicts of interest.

Correspondence concerning this article should be addressed to William R. Miller, PhD. Email:wrmiller@unm.edu privileged worlds of education and psychotherapy; although in fairness, Rogers did put his therapy to the test at Mendota State Hospital in a controlled trial with schizophrenia (Rogers, Gendlin, Kiesler \& Truax, 1967). It fascinates me that MI has been so readily and widely used on behalf of society's marginalized populations. In her meta-analysis, Jenny Hettema found that MI had twice the effect size when offered to minority populations, compared with White Americans (Hettema, Steele \& Miller, 2005).

We are building, of course, upon a strong foundation laid down by Carl Rogers and his students. Later in his life, Rogers (1980) came to understand the person-centered approach as a more general "way of being" with people, and he explored its potential applications in education, management, professions, political discourse, and social change. Now here I am doing the same.

It also fascinates me that so many people seem to be drawn to $\mathrm{MI}$ because in some sense they recognize it when they meet it-not as something strange that they are encountering for the first time, but as if it were something that they have known deeply and for a long time, like an old friend. To be sure, some professionals now come to Ml because of the accumulating evidence base or because they have learned it from the beginning of their training, but I sense that there is something more here. How did MI disseminate so quickly and widely-now in at least 45 languages - with virtually no marketing, and often well in advance of an adequate database? What is it that draws so many caring helpers to $\mathrm{MI}$ from so many different professions, nations, and contexts? It is as though we knew it by heart.

\section{HUMANE VALUES}

A radical aspect of Carl Rogers' work is that he placed such emphasis on the mindset and heartset, the spirit with which we work. Here is his own reflection on this:

I was dimly aware-fortunately, only dimly—that I was challenging almost all of the "sacred cows" in the therapeutic world. I was saying in effect, although not very openly, that it wasn't a question of whether the therapist had been psychoanalyzed, or had a knowledge of personality theory, or possessed expertise in diagnosis, or had a thorough 
acquaintance with therapeutic techniques. Rather, I was saying that the therapist's effectiveness in therapy depended on his or her attitudes. I even had the nerve to define what I thought those attitudes were (Rogers, 1980, p. 270).

What he saw over time was that the attitudes implicit in personcentered counseling (and dare I say, those we have made explicit in the spirit of MI) have implications far beyond professional helping relationships. They are a way of seeing, a way of being in the world. So what are these broader attitudes, these tendencies or dispositions?

C.S. Lewis (1944), among others, maintained that there are certain values that we innately share as human beings - that "certain attitudes are really true and others really false." We recognize and honor them, if not universally, at least widely. These have come to be called humane or humanistic values. They are shared with and advocated by, but not limited to the world's great religions. "Humanistic" is also the name commonly given to the third wave in psychotherapy - the human potential tradition championed by Rogers and Maslow, in response to its reductionist and mechanistic predecessors of psychoanalysis and behaviorism.

More recently, Karen Armstrong (2010) has advocated for commitment to compassion as a broad umbrella for humane values. Her on-line "Charter for Compassion" states that:

The principle of compassion lies at the heart of all religious, ethical and spiritual traditions, calling us always to treat all others as we wish to be treated ourselves. Compassion impels us to work tirelessly to alleviate the suffering of our fellow creatures, to dethrone ourselves from the centre of our world and put another there, and to honour the inviolable sanctity of every single human being, treating everybody, without exception, with absolute justice, equity and respect (www.charterforcompassion.org).

So what are these humane values? There are many descriptions. I will highlight a list of six core humane values. The first three are set forth as foundational ethical principles in the 1978 Belmont Report on the protection of human subjects that was a response to research atrocities in Nazi concentration camps and subsequently in the United States and other nations. These became the foundation for the protection of human participants in research.

\section{Compassion}

The first is called compassion by Armstrong (2010) and the Dalai Lama (2001). In ethics it is often called beneficence. Compassion in this sense is not an emotion but an intention, a predisposition to act in a benevolent and generous manner to alleviate suffering and promote the welfare of others. Its opposite, maleficence, is to harm others, or at least to act in one's own interest without regard to effects on others.

\section{Respect for Persons}

A corollary is an inherent respect for all persons. Every human person is of inherent worth and deserves to be treated with respect regardless of income, beliefs, or demographics. Rogers called this unconditional positive regard, which includes respect for autonomy and self-determination.

\section{Justice}

The third Belmont principle is justice - $a$ fundamental humane value for fairness and equity. Each individual is part of a larger community and deserves to be treated equally under the law and in opportunity. Many societies extend this to fairness in the distribution of 0 resources as well - to see that no one goes without basic human needs for food, clothing, shelter, safety, and healthcare.

\section{Human Potential}

Maslow and Rogers added a belief in human potential that can be realized, actualized. Given the right conditions, we can trust people to grow naturally in a positive direction. It is a hopeful, optimistic view of human nature, in contrast to the dark impulses of psychoanalysis or the blank slate of behaviorism. Every person has a telos, a healthy mature state toward which they will naturally develop if their growth is not distorted.

\section{Acceptance}

Fifth, there is acceptance, the prizing of differences-the attitude that variety is healthy and valuable in human nature as in biodiversity. This is more than toleration-putting up with differences. It is acceptance, and beyond that curiosity, and beneath that the valuing of differences.

\section{Collaboration}

Finally, there is a humane value of collaboration, of working together in partnership across differences toward common ends. Its opposite is coercion, the use of power differential to determine whose interests will be served. A lesson of history is that ultimately oppression is doomed-humans cast it off. Coercion by power sooner or later implodes.

I believe that at least these six humane values are in our best interest as a community, as a nation, as a species. The book The Spirit Level (Wilkinson \& Pickett, 2009) offers overwhelming evidence that a wide array of human miseries are directly related to the degree of wealth inequality in a nation, even in states within the United States: the greater the gap between rich and poor, the greater the suffering of both rich and poor. On average, as a people we are (regardless of income) less healthy, more obese, more depressed and anxious, take more psychiatric medications, have more teen pregnancies and infant mortality, more violence and homicide, more prisons, more alcohol/drug problems, and die younger, in direct proportion to the size of the gap between rich and poor. Living in an unjust society is bad for us all.

The truth and power of these humane attitudes are not unique or limited to counseling relationships. In studying the basic facilitative conditions of a person-centered approach in education, Rogers concluded that "Students of 'high level' teachers (those high in facilitative conditions) tended to show the greatest gains in learning. A sobering finding was that students of 'low level' teachers may actually be retarded in their learning by their teachers' deficiencies" (Rogers, 1980, p. 308). It is a striking parallel to what we have found in psychotherapy research, that high empathy facilitates change, and low empathy can be toxic (Moyers \& Miller, in press).

But I am saying that these humane values have a claim on us well beyond the testimony of scientific evidence. With Karen Armstrong, C.S. Lewis, the Dalai Lama and the great world religions, I believe that these attitudes, these humane values are simply true in an absolute sense. We intuitively recognize and honor them. They are also self-fulfilling prophecies-they are realized as we practice them. They are habits of consciousness that tend to emerge with the extended practice of mindfulness meditation or centering prayer (Keating, 1994). I was also struck, in our study of quantum change (Miller \& C'de Baca, 2001), that these people we interviewed, who like Ebenezer Scrooge had been hit by psychospiritual lightning, came to rather similar attitudes despite their huge diversity prior to these experiences. Among their realizations were that:

material reality is a small part of all that is 
the nature of God is a love and acceptance so profound that we cannot comprehend it

love is the essence of what we are, and are meant to be

shortcomings should be met with compassion and forgiveness

truth is not to be imposed

all people are profoundly linked.

I wondered whether these are "messages to humankind" trying to get through to us, and these transformed people just happened to be contemporary recipients. I go so far as to believe that these are things we are meant to be.

\section{HUMANE VALUES AND MOTIVATIONAL INTERVIEWING}

So what does all this have to do with motivational interviewing? We are, I believe, manifesting these same fundamental humane values in the practice of $\mathrm{MI}$, one person at a time. We embrace collaborative partnership and eschew coercion. We honor and respect the autonomy of each person. We value fairness, generosity, and equal regard for all. We believe that each person has wisdom, strengths, and motivation, and we seek to evoke them. We are interested in, curious about, and prize the differences among people, and we work hard to understand how the world looks from their perspective. We try to keep as our prime directive the other person's best interests, and to do no harm. These are explicit humane values in MI, attitudes of mind and heart to which we aspire in our practice.

But to practice where? Just within the confines of our consulting rooms? Only inside the MI tent? Those of you sitting here in this MINT Forum are involved in an astonishing array of efforts to live out these humane values well beyond professional practice. For the most part you say little or nothing about it; you just do it. Since Steve Rollnick is not here, I can point without embarrassing him to his volunteer efforts on behalf of children and to reduce suffering related to HIVIAIDS throughout Africa. I have seen inspiring efforts by you to change not only individuals, but whole schools, prisons, and service systems. Why do you do these things? It is related, I think, to why you are here, and why you were drawn to motivational interviewing in the first place.

So lacking data this time, let me tell you a story. In the church that I attend, we began packing and providing sack lunches on weekdays for homeless people in the park across the street. About two years ago, one of these men named Chris showed up on a Sunday morning for worship. He was dressed in street clothes, with disheveled hair, and somewhat intoxicated, but he sat attentively through the service adding an "Amen" or two to which we staid Presbyterians are not accustomed. He was welcomed. People talked to him, encouraged him to come back, and he did. We remembered his name, asked him how he was, asked what he needed, listened to him, and helped with a few basic needs. One Sunday morning, with a little more than usual alcohol on board, he stood up toward the end of the service and loudly proclaimed: "Pastor, I don't mean to kiss your butt, but you're the best damned preacher I ever heard!"

He began inviting his friends, and they, too, were welcomed. They invited their friends. After a few months, when someone asked for a sack lunch on Sunday, it occurred to us that these people were hungry on the weekend as well. So we began preparing a simple hot lunch for our park friends. Nobody is required to come to worship in order to be fed, but many of them do. We now have about ten park friends with us on any given Sunday morning, and it's clear that the respect, compassion, curiosity, conversations, and belief in their value and potential are far more important than the food. The first of them just got into his own apartment, is stabilized, looks unbelievably better, and now pitches in to help with serving lunch for his friends. Another has put together four months of sobriety for the first time in years. Two who were initially "unmotivated" to get off the street now are taking steps in that direction. Several have become a regular part of the community of St. Andrew church, and we miss them when they're not there.

Carl Rogers was right, that attitude is so important in healing. And it is not limited at all to professional helping relationships. The attitudes of compassion, respect, fairness, human potential, prizing of differences, and collaboration are indeed powerful in healing of individuals and communities. It is such a joy to see those values lived out in the community of MINT.

In my faith tradition we say that it is our task to comfort the afflicted and to afflict the comfortable. How might we practice these values with the privileged on behalf of social justice, with those who have power to change the future? American politics have degenerated into the precise opposite of these values, pursuing change through coercion, shame, blame, demand, and threat. Collaboration is seen as betrayal, compassion as weakness, truth and fairness as optional. What instead would be a nonviolent, evocative response to power? It is what Gandhi and Martin Luther King showed us. Could you sit in a politician's office and instead of arguing or trying to persuade, ask evocative open questions and reflect? Could you listen empathically to someone who seems to disagree with you dramatically, and seek points of agreement and collaboration? Could you evoke the compassion that is hard-wired and natural in us when we're not angry or afraid, and strengthen commitment to it?

It is natural to strive to be better. To do that, we must first recognize that we are less than we could be-to develop discrepancy, if you will. A conceptual problem that I have had with Rogers's personality theory, as I understand it, is his idea that to be mentally healthy is to have concordance between actual and ideal self. Is it really "fully functioning" to have no discrepancy between self-perception and ideal, or is that a personality disorder? It is healthy instead, I believe, to move toward a distant horizon, one that we might never reach individually, but that we can approach. It was Martin Luther King's unquenchable hope that "I may not get there with you, but we as a people will get there." My favorite Robert Frost poem, Take Something Like a Star, ends:

\section{It asks of us a certain height}

So when at times the mob is swayed

To carry praise or blame too far

We may take something like a star

To stay our minds on, and be staid.

These six humane values are a constellation of stars toward which to move, in our practice, in our training, and in all our affairs.

\section{REFERENCES}

Armstrong, K. (2010). Twelve steps to a compassionate life. New York: Alfred A. Knopf.

The Dalai Lama, \& Vreeland, N. (2001). An open heart: Practicing compassion in everyday life. New York: Little, Brown.

Hettema, J., Steele, J., \& Miller, W. R. (2005). Motivational interviewing. Annual Review of Clinical Psychology, 1, 91-111. 
Miller, W. R., \& Rose, G. S. (2009). Toward a theory of motivational interviewing. American Psychologist, 64, 527-537.

Keating, T. (2009). Intimacy with God: An introduction to centering prayer. New York: Crossroad Publishing.

Lewis, C. S. (1944). The abolition of man. Oxford: Oxford University Press.

Miller, W. R., \& Atencio, D. J. (2008). Free will as a proportion of variance. In J. Baer, J. C. Kaufman, \& R. F. Baumeister (Eds.). Are we free? Psychology and free will (pp. 275-295). New York: Oxford University Press.

Miller, W. R., \& C'de Baca, J. (2001). Quantum change: When epiphanies and sudden insights transform ordinary lives. New York: Guilford Press.

Miller, W. R., \& Rose, G. S. (2010). Motivational interviewing in relational context. American Psychologist 65(4), 298-299.

Moyers, T. B., \& Miller, W. R. (in press). Is low empathy toxic? Psychology of Addictive Behaviors.

Rogers, C. R. (1980). A way of being. Boston: Houghton Mifflin.

Rogers, C. R., Gendlin, E. T., Kiesler, D. J., \& Truax, C. B. (Eds.). (1967). The therapeutic relationship and its impact: A study of psychotherapy with schizophrenics. Madison, WI: University of Wisconsin Press.

Stanton, M. (2010). Motivational interviewing and the social context. American Psychologist, 65(4), 297-298.

United States National Commission for the Protection of Human Subjects of Biomedical and Behavioral Research. (1978). The Belmont report: Ethical principles and guidelines for the protection of human subjects of research. Ann Arbor, MI: University of Michigan Library. 